\title{
ІСТОРИЧНІ НАУКИ
}

DOI: https://doi.org/10.32839/2304-5809/2020-5-81-58

УДК 930.85(1-751.3) 477-41

Бова І.С., Заїка Н.Л.

Національний історико-етнографічний заповідник «Переяслав»

\section{ПАТРІОТИЧНИЙ ВЕКТОР ВИСТАВКОВИХ ПРОЕКТІВ «СОБОРНІСТЬ УКРАЇНИ» НАЦІОНАЛЬНОГО ІСТОРИКО-ЕТНОГРАФІЧНОГО ЗАПОВІДНИКА «ПЕРЕЯСЛАВ»}

Анотація. У статті досліджуються обставини та ідеологія формування виставкових проектів Національного історико-етнографічного заповідника «Переяслав» (далі НІЕЗ «Переяслав») у взаємодії із суспільним громадським активом Переяславщини. Автори роблять спробу синтезувати фрактаж частини виставкової та інших форм просвітницької діяльності Заповідника, проаналізувати вектор напрацьованих матеріалів виставкових проектів через принципи історичної достеменності та хронологічної послідовності. Джерелом для дослідження стали матеріали наукових концепцій продемонстрованих виставок, оригінальні документи періоду Української Народної Револющії 19171921 рр. із фондів НІЕЗ «Переяслав», спогади, інтерв'ю учасників револющійних подій кінця XX - початку XXI ст., фрото і відеоматеріали приватних архівів, автентичні речі, особисті документи. У статті відслідковуеться вплив реалізованих виставкових проектів на осмислення досвіду Майдану та формування історичної культури громадянського суспільства Переяславщини, їх патріотичну направленість, що задає вектор усвідомленості та власної ідентифікації. Тематика зазначених проектів показуе локально роль переяславців у державотворчих процесах нової та новітньої історії України та формує культуру історичної пам'яті.

Ключові слова: Переяслав, музей, виставковий проєкт, патріотичні заходи, Соборність України, Революція Гідності, артефакти, війна.

Bova Iryna, Zaika Nataliia

The national ethnographic reserve «Pereiaslav»

\section{PATRIOTIC VECTOR OF EXHIBITION «UNITY OF UKRAINE» AT THE NATIONAL ETHNOGRAPHIC RESERVE «PEREIASLAV»}

Summary. The article examines the circumstances and ideology of the formation of the exhibition and patriotic project of the Pereiaslav National Historical and Ethnographic Reserve in cooperation with the public activists of Pereiaslav Region. The authors attempt to synthesize the facts of the exhibition and other forms of activity, to analyze the conditions for creating a exhibition project through the principles of historical accuracy and chronological sequence. The source for the research were materials of scientific concepts of exhibitions, original documents of the Ukrainian National Revolution of 1917 - 1921 from the founds of the Reserve, memoirs, interviews of participants of revolutionary events of the late twentieth to the beginning of the twenty-first century. The article traces the impact of the project on understanding the experience of the square and shaping the historical culture of civil society. The subject of the project is aimed at highlighting the role of residents of Pereiaslav in the state-making processes of modern and modern history of Ukraine and the formation of a culture of historical memory. The major factor in the creation of the project was a significant public demand for patriotic activities. Initially, the project was outlined and required a convenient format for communication, permanent educational activities, and independent judgments about revolutionary events and the ability to analyze them. The implementation of the project took the form of various types of scientific and educational work. The main form of communication was the exhibition format, it was supplemented by cultural events, lectures, meetings, debates, the development of questionnaires for the sociological survey of students, cultural programs for ATO soldiers. To implement the project, a working group of researchers from different units of the Reserve was created each year, developing concepts for exhibitions and thematic events. Successful search and collecting activities have produced historical narratives, documents, and other artefacts. The structure of the exhibitions in the project was in the main features constant, only certain topics were added, depending on their relevance at the moment and the receipts of new material. Permanent additions and expansions were covered by events covering the events in the east of Ukraine and the losses of Pereiaslav warriors in the war of Russia with Ukraine. During the six years of the project, 6 exhibitions, 12 thematic events were held, more than 20 hours of lectures were read, students of Pereiaslav Gymnasium were interviewed etc. The prospect of implementing a exhibition-patriotic project is the creation of a permanent museum exhibition, which in the conditions of the continuation of the military aggression of the Russian Federation is especially relevant and aimed at educating a new political nation.

Keywords: Pereiaslav, museum, project, exhibition, events, Ukrainian community Revolution of Dignity, artefacts, war.

Постановка проблеми. Направленість

1 виставкових проєктів Національного історико-етнографрічного заповідника «Переяслав» (далі - НIЕЗ «Переяслав») - це фрормування історичної пам `яті, яка є основою національно-па- тріотичної свідомості українців. Доленосні події 2013-2014 років кинули виклик пострадянській системі та сколихнули процеси консолідації суспільства навколо ідеї української ідентичності. На тлі великих політично-суспільних зрушень 
відзначення Дня Соборності України стало особливо актуальним та демонструвало едність і зрілість українського суспільства. В музейній діяльності відзначення доленосної події відбувалося через проведення низки виставок та культурних заходів патріотичного спрямування, що відображали основні віхи фрормування державності нової і новітньої історії України у контексті суспільних рухів.

Мета статті полягає в аналізі процесу реалізащіі музейних проєктів щодо фрормування патріотичної свідомості. Їх основою стали презентовані виставки HIE3 «Переяслав» щодо висвітлення боротьби української спільноти за незалежність, територіальну цілісність, демократичні цінності нашої держави. У статті відслідковуеться вплив виставково-просвітницьких заходів на осмислення досвіду Майдану та формування історичної культури громадянського суспільства Переяславщини.

Для досягнення поставленої мети, застосовуючи методи аналізу та синтезу, а також наукового опрацювання наративу, речових матеріалів, дотримуючись принщипу історичної достеменності та хронологічної послідовності, автори мають вирішити наступні завдання: окреслити обставини, напрями та форми просвітницької діяльності колективу НIE3 «Переяслав»; означити активність громадськості Переяславщини у протестних акція; проаналізувати вплив експозицій виставок на суспільну думку містян та на виховання молоді.

Аналіз останніх досліджень і публікацій. Дана тематика допоки немає належного наукового висвітлення. Наразі, до 40-річчя науковця Ярослава Потапенка була опублікована стаття у співавторстві О. Висовень та Ю. Фігурного, в якій згадується виставкова діяльність НIE3 «Переяслав» у зазначеному контексті [1, с. 39]; у 2018 р. вийшла друком стаття Н. Заїки, в якій автор дає стислу інформацію про початки реалізації національно-патріотичних виставкових проєктів у НIЕЗ «Переяслав» [2].

Головним джерелом для дослідження стали матеріали наукових концепцій проведених виставок, оригінальні документи періоду Української Народної Револющії 1917-1921 рр. із фондів HIE3 «Переяслав» [3], спогади, інтерв'ю учасників революційних подій кінця XX - початку XXI ст., фото і відеоматеріали приватних архівів, автентичні речі, особисті документи.

Виклад основного матеріалу. Наукові співробітники НIЕЗ «Переяслав» розуміли, що розгортання громадських протестів 2013-2014 pp. набуває історичного масштабу та суспільного значення і потребує збереження унікальних свідчень, які опинилися в епіцентрі подій. Була проведена успішна пошукова та збиральницька робота наративу, документів, предметів із подальшим науковим опращюванням. Упродовж 2015-2020 рр. вони стали основою проведення низки виставок з метою висвітлення ролі переяславців у державотворчих процесах.

Презентація першої виставки національнопатріотичної спрямування у 2015 р. започаткувала її щорічне проведення. Головним чинником продовження роботи означеного виставкового проекту став значний запит суспільства. Тоді він окреслювався в загальних рисах та все ж вимагав ширшого формату спілкування, перма- нентної просвітницької діяльності. Це обєеднало спільноту однодумщів та сприяло налагодження співпраці 3 місцевими активістами, митцями, державними діячами. Виставковий проєкт став набирати рис освітньої платформи, яка служить джерелом знань історії, сприяе підвищенню рівня критичного мислення, розширенню світоглядних уявлень містян. Ідеологічний вектор виставок передбачав формування вмінь аналізу револющійних подій, як суспільного явища, об'єктивного та незалежного судження щодо них, здатності бачити їх історичні наслідки для Української держави.

Упродовж шести років проєкт відбувався у формі різних видів науково-освітньої роботи. Основним видом комунікації все ж залишався виставковий формат, його доповнювали культурологічні заходи, лекціі, зустрічі, диспути, розробка анкет для соціологічного опитування школярів, культурні програми для воїнів ООС (АТО). Робоча група створення виставок організовувалася щороку із наукових співробітників різних підрозділів. За цей період сфрормувався основний склад працівників реалізації такої культурної платформи: Н. Заїка, І. Бова, Л. Гладун, С. Дембіцький. В різні роки до них долучалися Т. Музика, М. Товкайло, Дмитро та Світлана Тетері, С. Зубер, Н. Павлик, В. Ткаченко, А. Іваненко, В. Бова, I. Дунайна; С. Вовкодав та I. Гайдаєнко здійснювали фотофріксацію та монтаж відео хронік проведених заходів. Реалізації проєкту всіляко сприяв генеральний директор О. Лукашевич.

Структура виставок вибудовувалася відповідно до принципів історичної достеменності та хронологічної послідовності показу основних етапів боротьби за незалежність та соборність держави: Українська революція 1917-1921 рр., Революції Гідності 2013-2014 рр., російсько-українська війна XXI ст. Структурна композиція була в основних рисах постійною, додавалися лише окремі теми, залежно від їх актуальності на поточний момент та надходження нових речових матеріалів. Постійного доповнення і розширення зазнавали теми, що висвітлюють події на Сході України та щодо втрат воїнів-переяславчан у російсько-українській війні.

Виставки проходили як у межах HIE3 «Переяслав», так і в інших закладах Переяслава. Ix відкриття приурочували до Дня Соборності України. Презентації передбачали запрошення гостей, учасників революційних подій. Тривалість виставок була різною - від одного тижня до місяця. Їх літописом стала книга відгуків, започаткована 22.01.2015 p.

Перша виставка «Сднаймося, браття, - у єдності сила!» демонструвалася в приміщенні Меморіального музею В. Заболотного НIЕЗ «Переяслав» та мала позитивний резонанс у суспільстві, зацікавила мешканців і гостей міста, про що свідчить її відвідуваність - понад 2000 осіб.

Виставка стала основою проведення культурно-патріотичних заходів:

- до відзначення шевченківських днів: «Майдан. «...а всім нам вкупі на землі / єдиномисліє подай / і братолюбіє пошли...» (Т. Шевченко)» зустріч з шевченкознавцем, письменником, членом Національної спілки письменників України, учасником подій на Майдані І. Шпиталем; 
- «Майдан нікому не пробачить зради» - творча зустріч з поетом, письменником В. Шовкошитним;

- до Дня Героїв Небесної Сотні: «Майдан боротьба українців за майбутне нації» - зустріч 3 місцевими активістами: М. Корпанюком (д-р iст. наук, профр.), Я. Потапенком (д-р іст. наук, проф.), Г. Токмань (д-р пед. наук, проф.), Т. Нагайком (канд. іст. наук.), настоятелем Вознесенського собору о. Михайлом (Трускавецьким), бандуристом М. Товкайлом (канд. іст. наук.), волонтерами О. Гичко, В. Щербиною.

У 2016 р. відбулися наступні дві виставки:

- «Герої не вмирають!» до Дня Соборності України, проходила в приміщенні районного будинку культури м. Переяслава; присвячена пам'яті Ярослава Потапенка - громадського активіста, активного учасника Революції Гідності, голови ради ГО «Майдан Переяславщини» у 2014-2016 рр.;

- «Майдан. Україна понад усе!» - до Дня Героїв Небесної Сотні в приміщенні Музею кобзарства НIE3 «Переяслав». У контексті виставки була розкрита тема участі та ролі кобзарів у історичних подіях сьогодення.

У 2017 р. в приміщенні актової зали НIЕЗ «Переяслав» була відкрита четверта виставка «Свободу не спинити!». Слід відзначити, що вона зібрала велику кількість відвідувачів. Знаковою подією відкриття стала презентація збірника наукових статей, присвяченого пам `ті Я. Потапенка.

У 2018 р. виставкові проєкти мали продовження у форматі заходу «Запали вогонь пам яті», що відбувся у центральній районній дитячій бібліотеці.

В наступні роки проведення заходів стає ширшим, отримуе більший запит у суспільстві та набувае позитивного резонансу. Свідченням цього стало масштабне відкриття виставки «Соборність України: боротьба продовжуеться...» 2019 р. в приміщенні ДПТНЗ «Переяслав-Хмельницький центр професійно-технічної освіти». Були присутні політичні та громадські діячі державного рівня, учасники революційних подій, представники мистецького середовища (письменник Р. Коваль, кобзар Т. Силенко, композитор В. Мартишко). Акція «Рушник Великому Тарасу» доповнила програму відкриття. Виставка стала освітньою платформою проведення диспутів та лекцій, тематичних заходів для учнів ДПТНЗ «Переяслав-Хмельницький центр професійнотехнічної освіти».

Цього ж року у рамках реалізації виставкового проекту відбулися заходи у центральній районній дитячій бібліотещі:

- «Небесна сотня - Герої нашого часу» до днів вшанування пам'яті Героїв Небесної Сотні;

- «Вільні творити майбутне» до Дня Гідності і Свободи.

У 2020 р. у КЗ КОР «Переяславський ліцейінтернат «Патріот» відбулася виставка «Сила нації - в едності!». Ї̈̈ відкриття модерував «голос переяславського Майдану» [4, с. 34]) - Ю. Бобровник (канд. іст. наук). Були присутні полков- ник О. Дорохов, командир 43-ої артилерійської бригади (в/ч с. Дівички), полковник М. Барилко, представник Міжнародного міжвідомчого багатопрофільного центру підготовки підрозділів НГУ, поетеса 3. Галущенко, мати загиблого А. Галущенка (позивний «Ендрю»), який посмертно нагороджений орденами «Народний герой України», «За мужність» III ступеня.

Майданчик виставки став основою проведення наступних заходів:

- «Волонтерський рух Переяславщини» за участі місцевих волонтерів I. Марченко та М. Швиденко;

- Зустріч із авторкою книги «Простір прихованого (Нотатки з військового шпиталю)» Р. Товкайло;

- зустріч з «кіборгом» Л. Хмельковим;

- «Співці свободи сьогодення» - зустріч з кобзарем М. Товкайло, цехмайстром Київського цеху бандуристів;

-«На шляху до свободи» - зустріч з О. Гичко, активісткою переяславського та київського Майданів;

- «Неймовірна відвага і хоробрість юних сердещь» до дня Героїв Крут.

Кількість і якість проведених заходів початку 2020 р. показали позитивну динаміку росту ефективності роботи виставкових проєктів.

Висновки і пропозиції. Україна є невід'ємною складовою единого европейського цивілізаційного та політичного простору. Проблема збереження національної ідентичності в умовах глобалізації стоїть досить гостро і неможлива без реалізації культурно-патріотичних заходів на містечковому рівні, які впливають на цілісність і едність спільноти у векторі розвитку держави.

Узагальнюючи вище сказане, ми прийшли висновку, що:

- науково-просвітницька діяльність співробітників HIE3 «Переяслав» має запит у суспільстві та реалізуеться як широкий спектр різних форм роботи у закладах міста;

- виставкові проєкти НІЕЗ «Переяслав» відіграють важливу роль у формуванні культури історичної пам'яті громадськості Переяславщини;

- для реалізації виставкових проєктів була проведена пошукова роботу та зібрано понад 500 артефактів та усних свідчень;

- за шість років проведено 6 виставок, 12 тематичних заходів, прочитано понад 20 год. лекторію, проведене анкетування учнів Переяславської гімназії тощо;

- перспективою у реалізації зазначених проєктів е перехід від тимчасових виставок до постійно діючої музейної експозиції.

Започатковані патріотичні проекти культурнопросвітницької діяльності НIE3 «Переяслав» у історичному періоді нинішньої складної політичної ситуації в Україні мають продовження. Вони, як інструмент масової культури, необхідні для закладання основи осмислення стратегії результатів соціально-політичних перетворень у державі та формування історичної культури соціуму. 


\section{Список літератури:}

1. Висовень О., Фігурний Ю. Державотворча, націєтворча та етнокультурна діяльність патріота-націоналіста Ярослава Потапенка (1975-2016). Кафедра історії та культури України Наукові записки з української історії: Зб. наук. ст. Переяслав-Хмельницький (Київ. обл.) : Домбровська Я.М., 2016. Вип. 40 (Спецвипуск). С. 33-40.

2. Заїка Н.Л. Участь переяславців у Революції Гідності 2013-2014 років. Виставкові проекти Національного історико-етнографічного заповідника «Переяслав». Україна - на шляху до Незалежності. Збірник матеріалів науково-практичної конференції. 7 грудня 2017 року. Редкол. П.Я. Степенькіна (відп. ред.) та ін. КорсуньШевченківський : ФОП Майдаченко I.В., 2018. С. 233-237.

3. Фонди Національного історико-етнографічного заповідника «Переяслав». Інвентарні книги фрондових груп «Науково-допоміжний фонд» (шифр «НДФ») №№ 1-9, «Рукописні та друковані матеріали» (шифр «Р») №№ $1-9$.

4. Токмань Г. Майдан: сторінки живої історії. 3-те вид., виправл. і доповн. Ніжин : вид. ПП Лисенко М.М., 2016. 102 с., іл.

\section{References:}

1. Vysoven, O., \& Fihurnyi, Yu. (2016). Derzhavotvorcha, natsiietvorcha ta etnokulturna diialnist patriotanatsionalista Yaroslava Potapenka (1975-2016). Kafedra istorii ta kultury Ukrainy Naukovi zapysky z ukrainskoi istorii: Zb. nauk. st. Pereiaslav-Khmelnytskyi (Kyiv. obl.): Dombrovska Ya.M., vyp. 40 (Spetsvypusk), pp. 33-40.

2. Zaika, N.L. (2018). Uchast pereiaslavtsiv u Revoliutsii Hidnosti 2013-2014 rokiv. Vystavkovi proekty Natsionalnoho istoryko-etnohrafichnoho zapovidnyka «Pereiaslav». Ukraina - na shliakhu do Nezalezhnosti. Zbirnyk materialiv naukovo-praktychnoi konferentsii. 7 hrudnia 2017 roku. Redkol. P.Ya. Stepenkina (vidp. red.) ta in. Korsun-Shevchenkivskyi: FOP Maidachenko I.V., pp. 233-237.

3. Fondy Natsionalnoho istoryko-etnohrafichnoho zapovidnyka «Pereiaslav». Inventarni knyhy fondovykh hrup «Naukovo-dopomizhnyi fond» (shyfr «NDF») №№ 1-9, «Rukopysni ta drukovani materialy» (shyfr «R») №№ 1-9.

4. Tokman, H. (2016). Maidan: storinky zhyvoi istorii. 3-tie vyd., vypravl. i dopovn. Nizhyn: vyd. PP Lysenko M.M., 102 p. 